\title{
PENGEMBANGAN MODUL PEMBELAJARAN IPA BERBASIS PENDEKATAN KONSTRUKTIVISME UNTUK KELAS V SD
}

\section{DEVELOPMENT OF IPA-BASED LEARNING MODULE CONSTRUCTIVISM APPROACH FOR GRADE V STUDENTS}

\author{
Rona Taula Sari ${ }^{{ }^{*}}$, Siska Angreni ${ }^{1}$, Retno Aulia Fortuna ${ }^{1}$ \\ ${ }^{1}$ Universitas Bung Hatta, Jl. Bagindo Aziz Chan, Jl. By Pass, Aie Pacah, Kec. Koto Tangah, Kota Padang, Sumatera Barat 25586 , \\ Indonesia \\ *Corresponding authors: ronataulasari21@gmail.co.id
}

Manuscript received: Revision accepted:

\begin{abstract}
This research aims to describe the validity and practicality of IPA learning module based on constructivism approach to the material adaptation of plants to certain environments to sustain life in valid and practical class $\mathrm{V}$ elementary school students. This type of research is Research and Development. The science learning module based on the constructivism approach was developed using 3-D models. This research was conducted in the even semester of the 2018/2019 school year. Data collection is done by validation and testing of modules developed. The module design that was designed was validated by two expert lecturers and then tested in class V of SD Negeri 07 Lubuk Jantan to find out the practicality and validity of the modules developed. The results of the study found that the science learning module based on the constructivism approach on the material adaptation of plants to certain environments to sustain life for students in grade $\mathrm{V}$ elementary school is in the category of very valid with an average validity of 3.65 . The modules that have been developed are categorized as very practical by educators with an average percentage of practicality of $91 \%$, also categorized as very practical according to students with an average percentage of practicality of $91 \%$. This shows that the science learning module is based on a constructivism approach to the material adaptation of plants to certain environments to maintain the life produced is very valid and very practical so that it can be used in learning in class $\mathrm{V}$ $\mathrm{SD}$.
\end{abstract}

Keywords: IPA module, Constructivism, Validity, Practicality

\section{PENDAHULUAN}

Pendidikan merupakan aktivitas sadar yang diarahkan untuk menumbuh kembangkan potensi sumber daya manusia melalui kegiatan pembelajaran. Pembelajaran merupakan interaksi antara pendidik dengan peserta didik, peserta didik dengan pendidik atau peserta didik dengan peserta didik itu sendiri untuk meningkatkan potensi peserta didik (Sari, 2017;53); (Sari, 2018;15); (Sari, 2018;79). Namun, kenyataan yang dihadapi dunia pendidikan dalam mengembangkan potensi peserta didik adalah permasalahan proses pembelajaran. Proses pembelajaran yang terjadi di dalam kelas lebih diutamakan pada perolehan kemampuan kognitif, peserta didik lebih dituntut untuk menghafal pelajaran yang diberikan tanpa harus memahami dan menghubungkan pembelajarannya dengan kehidupan sehari-hari, sehingga ketika peserta didik lulus dari sekolah mereka hanya pandai dalam teori tetapi lemah dalam pengaplikasian dikehidupan sehari-hari.

Oleh karena itu, pendidik sebagai fasilitator memiliki peran yang sangat besar dalam menciptakan generasi yang mampu menerapkan ilmu yang diperoleh dalam kehidupan sehari-hari. Sari (2016;162); Sari $(2017 ; 27)$ menyatakan bahwa pendidik harus mampu mengarahkan peserta didik melalui proses pembelajaran bermakna yang dialaminya sendiri sehingga mampu menerapkan pengetahuannya di dalam kehidupan sehari-hari. Oleh karena itu, pendidik harus mampu menciptakan pembelajaran yang aktif dan berpusat kepada peserta didik (studen center). Salah satu upaya yang dapat dilakukan dalam meningkatkan pengetahuan peserta didik dalam proses pembelajaran adalah pembelajaran yang aktif dengan menitik beratkan kepada peserta didik. Salah satu cara untuk meningkatkan proses pembelajaran yaitu dengan menggunakan modul pembelajaran, karena modul pembelajaran diketahui dapat meningkatkan proses pembelajaran mandiri oleh peserta didik.

Menurut Sari (2017:23); Sari (2017;54); Handayani $(2019 ; 8)$ modul merupakan kesatuan sumber belajar yang dirancang untuk membantu peserta didik dalam mencapai tujuan pembelajaran. Modul disebut juga media untuk belajar mandiri karena di dalamnya telah dilengkapi petunjuk untuk belajar mandiri. Artinya, peserta didik 
dapat melakukan kegiatan belajar tanpa kehadiran pendidik secara langsung.

Upaya untuk melatih ranah kognitif, afektif, dan psikomotor, maka diperlukannya pengembangan modul yang menggunakan pendekatan pembelajaran yang mampu membimbing peserta didik untuk berpikir dan memecahkan masalah serta membangun pengetahuan yang dimilikinya. Salah satu pendekatan yang dapat digunakan dalam melatih ranah kognitif, afektif, dan psikomotor peserta didik yaitu modul dengan berbasis pendekatan konstruktivisme. Menurut Amrah (2019;450); Sari (2017:23); Sari $(2017 ; 55)$; Supardi (2019;80) pembelajaran konstruktivisme adalah proses belajar yang diawali dengan adanya konflik kognitif yang bisa dipecahkan melalui pengetahuan peserta didik, dimana pengetahuan peserta didik dibangun dari pengalamannya dengan lingkungan. Pembelajaran konstruktivisme ini menekankan pada interaksi sosial peserta didik serta cara peserta didik dalam menemukan konsep dari penyelidikan dan pengumpulan data melalui kegiatan yang telah dirancang oleh pendidik seperti pengamatan, percobaan, diskusi, tanya jawab, dan membaca buku.

Berdasarkan hasil observasi dan wawancara yang peneliti lakukan dengan pendidik kelas V SD Negeri 07 Lubuk Jantan yaitu pada tanggal 26, 27 dan 29 Oktober 2018. Terlihat pada proses pembelajaran, pendidik masih menggunakan metode ceramah sehingga pembelajaran lebih terpusat pada pendidik (Teacher Center) dan belum membangun pengetahuan peserta didik. Sumber pembelajaran yang digunakan berupa Lembar Kerja Siswa (LKS) dan buku cetak dari penerbit komersil. Selain itu, dalam proses pembelajaran pendidik belum memiliki modul pembelajaran dengan menggunakan model konstruktivisme. Hal ini disebabkan karena proses pembuatan modul yang membutuhkan waktu dan juga biaya yang cukup banyak. Sementara itu, peserta didik memerlukan sumber bacaan yang dapat menunjang proses pembelajaran yang melatih ranah kognitif, afektif dan psikomotor sehingga dapat membimbing peserta didik untuk berpikir dan memecahkan masalah serta dapat membangun pengetahuannya. Selain itu, saat observasi ditemukan buku paket yang tersedia hanya menuntut peserta didik untuk menghafal materi pelajaran tanpa harus memahami materi tersebut sehingga hasil belajar peserta didik masih rendah.

Berdasarkan uraian tersebut perlu dilakukan pengembangan modul pembelajaran yang dapat membantu membangun pengetahuan peserta didik.

Diharapkan dengan menggunakan modul pembelajaran berbasis pendekatan konstruktivisme peserta didik bisa memahami pembelajaran dengan mudah, karena dalam pandangan konstruktivisme seseorang memiliki pengetahuan yang dimiliki sejak lahir dan dikembangkan secara terbatas dan tidak tiba-tiba. Oleh karena itu, peneliti melakukan penelitian yang berjudul "Pengembangan Modul Pembelajaran IPA Berbasis Pendekatan Konstruktivisme untuk Kelas V SD Negeri 07 Lubuk Jantan".

\section{METODE PENELITIAN}

Penelitian ini merupakan penelitian pengembangan (Research and Development) yang dilakukan di kelas V SD Negeri 07 Lubuk Jantan Kabupaten Tanah Datar. Data pada penelitian diperoleh secara langsung dari dosen, pendidik dan peserta didik yang diambil melalui angket pengujian validitas dan praktikalitas. Dimana data tersebut, yaitu (1) skor validasi dari dosen ahli (2) skor angket respon oleh pendidik, (3) skor angket respon oleh peserta didik.

Instrumen Penelitian yang digunakan yaitu instrumen validasi yang berisi aspek penilaian yaitu aspek didaktik, konstruksi dan teknik. Lembar praktikalitas modul yang diisi oleh pendidik berisi aspek kepraktisan penggunan, kesesuaian waktu, kesesuaian ilustrasi dan bahasa yang digunakan. Angket respon pendidik dan peserta didik digunakan untuk mendapatkan respon terhadap praktikalitas modul pembelajaran yang dikembangkan. Instrumen ini di isi oleh peserta didik setelah mengikuti proses pembelajaran dan pendidik setelah melaksanakan pembelajaran

\section{Analisis Data Hasil Validasi Modul Pembelajaran}

Data hasil validasi modul pembelajaran yang diperoleh, dianalisis terhadap seluruh aspek yang disajikan dalam bentuk tabel dengan menggunakan Skala Likert, selanjutnya dicari rata nilai dengan menggunakan rumus berikut (Sari, 2017:24).

$$
\boldsymbol{R}=\frac{\boldsymbol{V} \boldsymbol{i j}}{\mathbf{n m}}
$$

Dengan :

$\mathrm{R}=$ rata-rata hasil penelitian dari para ahli/praktisi

$\mathrm{Vij}=$ skor hasil penelitian para ahli/praktisi ke-j kriteria $\mathrm{i}$

$\mathrm{n}$ = banyaknya para ahli yang menilai

$\mathrm{m}=$ banyak cerita

Menurut Sari (2017:24) prosedur penetapan tingkat kevalidan didapatkan dengan kriteria seperti tabel 1 berikut:

Tabel 1 Kriteria Penetapan Tingkat Kevalidan

\begin{tabular}{|c|c|}
\hline Rentang & Kategori \\
\hline $0-54 \%$ & Sangat tidak praktis \\
\hline $55-59 \%$ & Kurang praktis \\
\hline $60-75 \%$ & Cukup praktis \\
\hline $76-85 \%$ & Praktis \\
\hline $86 \%-100 \%$ & Sangat praktis \\
\hline
\end{tabular}

\section{Analisis Hasil Praktikalitas Modul}

Data uji praktikalitas modul pembelajaran IPA berbasis pendekatan konstrutivisme dianalisis dengan rumus sebagai berikut (Yanti, 2014:130). 


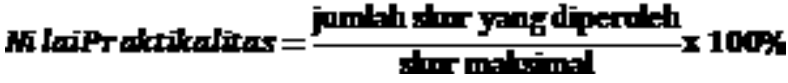

Tabel 2 Kriteria Penetapan Respon Peserta didik

\begin{tabular}{cc}
\hline Rentang & Kategori \\
\hline $0-54 \%$ & Sangat tidak praktis \\
$55-59 \%$ & Kurang praktis \\
$60-75 \%$ & Cukup praktis \\
$76-85 \%$ & Praktis \\
$86 \%-100 \%$ & Sangat praktis \\
\hline
\end{tabular}

\section{HASIL DAN PEMBAHASAN}

\section{Hasil Validasi Modul Pembelajaran}

Modul pembelajaran IPA berbasis pendekatan konstruktivisme yang dirancang dilanjutkan kepada validator untuk dilakukan validasi. Validasi bertujuan untuk mendapatkan saran agar modul pembelajaran IPA berbasis pendekatan konstruktivisme yang dikembangkan menjadi modul yang berkualitas secara aspek didaktik, aspek konstruksi dan aspek teknik. Hasil validasi dari ahli (dosen pengampu matakuliah IPA dan media pembelajaran) dipergunakan sebagai revisi modul. Data yang diperoleh dari penilaian ahli tersaji dalam tabel 3 .
Indikator penilaian aspek didaktik yaitu modul yang dikembangkan sesuai dengan kurikulum KTSP 2006, kelengkapan dan kejelasan materi, membantu peserta didik mengkonstruksikan pengetahuan dan membantu peserta didik menemukan konsep. Hal ini sesuai dengan pendapat Sari (2017:24) yaitu modul dinyatakan sudah memenuhi syarat didaktik karena materi sesuai dengan kurikulum yang berlaku, dapat mendukung pemahaman konsep, membantu peserta didik mengkonstruksi pengetahuannya, serta dapat meningkatkan efektivitas dalam proses pembelajaran.

Untuk aspek konstruksi yaitu 3,67 dengan kategori sangat valid, dimana indikator penilaiannya adalah susunan kalimat yang mudah dipahami, terdapat informasi tambahan, dan sesuai dengan Ejaan Bahasa Indonesia (EBI). Menurut Sari (2017:25) modul dinyatakan sangat valid oleh validator karena susunan modul pembelajaran yang dikembangkan telah memenuhi syarat-syarat penyusunan modul pembelajaran yang baik, di antaranya kejelasan petunjuk, kejelasan format, penyusunan materi dan kesesuaian antara materi dengan modul pembelajaran sehingga membantu peserta didik dalam memahami materi.

Selain itu, modul juga dinyatakan memenuhi syarat teknis karena tujuan, gambar, warna, susunan materi yang sistematis,serta kejelasan petunjuk dan kejelasan format. Hal ini bisa dilihat pada perolehan nilai rata-rata aspek teknis yaitu 3,64 dengan kategori sangat praktis. Hal ini, memandakan modul yang dikembangkan memiliki kejelasan petunjuk, modul dijabarkan dapat menuntun peserta didik menemukan konsep sesuai dengan tujuan pembelajaran dan dapat memfasilitasi peserta didik belajar mandiri serta evaluasi dalam modul pembelajaran yang telah dikembangkan dapat mengukur ketercapaian kompetensi. Menurut Pribadi (2010:138) mengemukakan bahwa konstruktivisme menuntut peserta didik belajar dan membangun pengetahuan manakala peserta didik berupaya untuk memahami lingkungan yang ada di sekitar diri peserta didik serta dapat meningkatkan pemahaman terhadap konsep-konsep dan prinsip yang dipelajari.

Berdasarkan validasi dari validator modul pembelajaran IPA berbasis pendekatan konstruktivisme yang dikembangkan berada pada kategori sangat valid. Hal ini diperoleh dari hasil validator yaitu 3,65. Dan dapat dikatakan keabsahan isi modul dapat dipertanggung jawabkan karena telah divalidasi oleh dosen ahli.

\section{Praktikalitas Modul Pembelajaran}

Praktikalitas modul pembelajaran oleh pendidik

Analisis hasil uji praktikalitas oleh pendidik kelas V SD Negeri 07 Lubuk Jantan menunjukkan modul pembelajaran IPA berbasis pendekatan konstruktivisme pada materi penyesuaian diri tumbuhan dengan lingkungan tertentu untuk mempertahankan hidup sangat praktis dengan persentase kepraktisan 91\%. Hal ini menunjukkan bahwasannya modul pembelajaran yang dikembangkan dapat mempermudah pendidik dalam menjelaskan materi IPA serta membantu peran pendidik spek diketahui bahwa secara keseluruhan pada kategori sangat baik. Sehingga rata-rata validasi modul oleh ahli berada pada kategori sangat valid dengan nilai 3,65 . 
sebagai fasilitator. Hal ini sejalan dengan pendapat Rosa (2015:53) bahwa modul merupakan bahan ajar yang dapat digunakan oleh peserta didik untuk belajar secara mandiri dengan bantuan seminimal mungkin dari pendidik.

Modul pembelajaran merupakan sumber belajar yang dapat dimanfaatkan oleh peserta didik dalam proses pembelajaran. Pemanfaatan sumber-sumber belajar dapat membantu meningkatkan efektivitas dan efisiensi dalam proses pembelajaran. Hasil praktikalitas modul pembelajaran IPA berbasis pendekatan konstruktivisme kepraktisan penggunaan dinyatakan sangat praktis dengan persentase $90 \%$. Hal ini menunjukkan bahwa modul pembelajaran mudah digunakan, materi yang dapat mengkonstruksikan pengetahuan peserta didik, serta menarik minat dan mudah dipahami. Menurut Trianto (2012:74) konstruktivisme adalah suatu proses dimana peserta didik secara aktif membangun pemahaman terhadap realita melalui pengalaman dan interaksi mereka dengan cara terus-menerus mengasimlasi dan mengakomodasi informasi baru, dengan kata lain konstruktivisme adalah teori perkembangan kognitif yang menekankan peran aktif peserta didik dalam membangun pemahaman mereka.

Dari aspek efektivitas waktu pembelajaran modul pembelajaran IPA berbasis pendekatan konstruktivisme, modul pembelajarn dinyatakan praktis dengan pesersentase $83 \%$. Hal ini menunjukkan bahwa modul yang dikembangkan dapat meningkatkan proses pembelajaran menjadi efektif. Hal ini sejalan dengan pendapat Mufidah (2014:6) fungsi bahan ajar oleh pendidik yaitu: menghemat waktu pendidik dalam mengajar dan meningkatkan proses pembelajaran menjadi lebih efektif dan interaktif. Lanjutnya modul diartikan sebagai materi yang disusun dan disajikan sedemikian rupa sehingga peserta didik dapat menyerap materi. Pada saat ujicoba modul pembelajaran terhadap peserta didik kelas V SD Negeri 07 Lubuk Jantan terdapat kendala yaitu beberapa gambar yang tersedia pada modul pembelajaran jarang dijumpai oleh peserta didik dalam kehidupan sehari-hari dan juga peserta didik diberikan materi setelah peserta didik megerjakan beberapa latihan sehingga memperlama waktu pembelajaran.

Selanjutnya aspek kesesuaian ilustrasi dinyatakan sangat praktis dengan persentase $100 \%$. indikator penilaian ini yaitu kejelasan petunjuk atau ilustrasi yang terdapat pada modul pembelajaran sehingga dapat meningkatkan minat peserta didik. Menurut Sari (2017:25) modul yang memuat banyak gambar dan objek sesuai dengan tuntunan materi yang terpapar pada modul, dapat meningkatkan minat peserta didik terhadap materi pembelajaran. Dan dari aspek bahasa dinyatakan sangat praktis dengan persentase 92\%. Hal ini menunjukkan bahwasannya modul pembelajarn yang dikembangkan memuat gambar/ilustrasi dan kalimat yang menarik untuk dibaca.

\section{Praktikalitas modul pembelajaran oleh peserta didik}

Analisis data hasil uji praktikalitas oleh peserta didik kelas V SD Negeri 07 Lubuk Jantan menunjukkan bahwa modul
IPA berbasis pendekatan konstruktivisme pada materi penyesuain diri tumbuhan dengan lingkungan tertentu untuk mempertahankan hidup yang telah dikembangkan sangat praktis dengan persentase kepraktisan 91\%. Persentase tersebut didapatkan dari rata-rata indikatorindikator penilaian.

Indikator yang dinilai yaitu tampilan modul pembelajaran, huruf yang digunakan, manfaat modul dalam membantu peserta didik untuk belajar mandiri, serta penyajian gambar yang terdapat pada modul pembelajaran. Penggunaan modul pembelajaran berbasis pendekatan konstruktivisme mendorong partisipasi aktif peserta didik dalam proses pembelajaran. Warna-warna yang dipilih untuk gambar, teks, dan latar belakan pada setiap shapes serta page color merupakan warna-warna kontras yang mendukung minat peserta didik terhadap modul pembelajaran. Menurut Rahmat (2010:277) warna memiliki efek fisologis terhadap kecemasan, denyut jantung, dan aliran darah. Setiap warna memiliki panjang gelombang dan setiap panjang gelombang dapat mempengaruhi tubuh dan otak secara berbeda. Warna yang banyak digunakan adalah, biru, hijau dan kuning.

Berdasarkan uraian diatas, maka dapat disimpulkan bahwa modul pembelajaran IPA berbasis pendekatan konstruktivisme yang dikembangkan sangat praktis. Hal ini berarti dapat digunakan oleh sekolah uji coba.

\section{KESIMPULAN}

Berdasarkan pengembangan data uji coba modul pembelajaran IPA berbasis pendekatan konstruktivisme pada materi penyesuaian diri tumbuhan dengan lingkungan tertentu untuk mempertahankan hidup yang telah dilakukan, diperoleh kesimpulan sebagai berikut.

Validitas modul pembelajaran IPA berbasis pendekatan konstruktivisme pada materi penyesuaian diri tumbuhan dengan lingkungan tertentu untuk mempertahankan hidup untuk kelas V SD Negeri 07 Lubuk Jantan yang telah dikembangkan dinyatakan sangat valid dengan rata-rata 3,7 .

Praktikalitas modul pembelajaran IPA berbasis pendekatan konstruktivisme pada materi penyesuaian diri tumbuhan dengan lingkungan tertentu untuk mempertahankan hidup untuk kelas V SD Negeri 07 Lubuk Jantan yang telah dikembangkan dinyatakan sangat praktis dengan rata-rata persentase kepraktisan 91\% oleh pendidik dan dinyatakan sangat praktis dengan rata-rata persentase kepraktisan $91 \%$ oleh peserta didik.

\section{UCAPAN TERIMA KASIH}

Kami ucapkan terima kasih banyak kepada seluruh pihak yang telah membantu penelitian ini.

\section{DAFTAR PUSTAKA}

Amrah, A. (2019). PENINGKATAN HASIL BELAJAR IPA SISWA KELAS V TEMA 6 PANAS DAN PERPINDAHANNYA MENGGUNAKAN 
KONSTRUKTIVISME. Jurnal Pendidikan Tambusai, 3(1), 450-460.

Handayani, T. L., Sugianto, S., \& Susanto, H. (2019). Pengembangan Modul Pembelajaran Berbentuk PopUp dan Smash Book Materi Sifat Cahaya Bagi Siswa Penyandang Disabilitas Rungu. UPEJ Unnes Physics Education Journal, 8(1), 8-15.

Mufidah,C.I.2014.Pengembangan Modul Pembelajaran Pada Kompetensi Dasar Hubungan Masyarakat Kelas $\mathrm{X}$ APK 2 di SMKN 10 Surabaya. Jurnal Administrasi Pekantoran (JPAP),2(2).

Pribadi, B. A. 2010. Pendekatan Konstruktivis dalam Kegiatan Pembelajaran. Jalarta:PT. Dian Rakyat.

Rosa, Friska Oktavia.2015. Pengembangan Modul Pembelajaran IPA SMP pada Materi Tekanan Berbasis Keterampilan Proses Sains. Jurnal Pendidikan Fisika 3.1. 49-63.

Sari, R. T. (2016). Analisis Perencanaan Pembelajaran IPA pada Materi Ekosistem Kelas XII SMK Negeri 4 Padang. Varia Pendidikan Kajian Penelitian Pendidikan, 28(2), 0852-0976.

Sari, R. T. (2017). Uji Validitas Modul Pembelajaran Biologi Pada Materi Sistem Reproduksi Manusia Melalui Pendekatan Konstruktivisme Untuk Kelas IX SMP. Scientiae Educatia: Jurnal Pendidikan Sains, 6(1), 22-26.

Sari, R. T. (2017). EFEKTIFITAS MODUL PEMBELAJARAN BIOLOGI MELALUI PENDEKATAN KONSTRUKTIVISME. PAKAR PENDIDIKAN, 15(1), 53-66.

Sari, R. T., \& Jusar, I. R. (2017). Analisis Kebutuhan Modul Pembelajaran IPA Berorientasi Pendidikan Karakter Melalui Pendekatan Quantum Learning Di Sekolah Dasar. BIOEDUKASI (Jurnal Pendidikan Biologi), 8(1), 26-32.

Sari, R. T., \& Jusar, I. R. (2018). Analysis of science learning process by using learning module of character education oriented through quantum learning approach. Jurnal Penelitian dan Pembelajaran IPA, 4(1), 14-24.

Sari, R. T., \& Angreni, S. (2018). Penerapan Model Pembelajaran Project Based Learning (PjBL) Upaya Peningkatan Kreativitas Mahasiswa. Jurnal Varidika, 30(1), 79-83.

Supardi, A. A., Gusmania, Y., \& Amelia, F. (2019). Pengembangan Modul Pembelajaran Matematika Berbasis Pendekatan Konstruktivisme Pada Materi Logaritma. AKSIOMA: Jurnal Matematika dan Pendidikan Matematika, 10(1), 80-92.
Trianto,M.Pd. 2012. Model Pembelajarn Terpadu Konsep, Strategi, dan Implementasinya dalam Kurikulum Tingkat Satuan Pendidikan (KTSP). Jakarta : Bumi Aksara. 